\title{
Profit Distributed from Czech Construction SUBSIDIARIES TO FOREIGN PARENT COMPANY
}

\author{
Jan Berný*1, Jana Frková \\ ${ }^{1}$ The Czech Technical University in Prague, Faculty of Civil Engineering, Thákurova 7, Praha 6, 166 29, \\ Czech Republic, jan.berny@fsv.cvut.cz \\ ${ }^{2}$ The Czech Technical University in Prague, Faculty of Civil Engineering, Thákurova 7, Praha 6, 166 29, \\ Czech Republic, frkova@fsv.cvut.cz, https://orcid.org/0000-0003-4028-8312
}

\begin{abstract}
Payment of profit shares means that the company's equity is decreased by the value of dividends paid. The article focuses on the issue of how foreign parent of Czech construction companies approach this. Whether they reinvest the profit and are interested in the development of the Czech subsidiary or whether and to what extent they draw on profits. The four largest construction companies were selected, of which one owned by Czech owners was selected for comparison, the other three companies are $100 \%$ owned by foreign capital. Within the EU, the Czech Republic is the country from which most funds go abroad in the form of dividends in relation to the size of GDP. How the construction industry contributes to this outflow and how the three largest foreign construction companies on the Czech market contribute to this, the article answers these questions.
\end{abstract}

\section{Keywords}

Construction companies, profit distribution, shareholders

\section{JEL Classification}

M21 Business Economics

DOI: https://doi.org/10.14311/bit.2021.01.04

Editorial information: journal Business \& IT, ISSN 2570-7434, CreativeCommons license (c) (i) published by CTU in Prague, 2021, http://bit.fsv.cvut.cz/

\section{Introduction}

Let us first recall the basic postulates: The purpose of business is to make a profit. Profit is also a measure of success. However, the condition for success is sustainable cash flow. Profit as the difference between income and expenses is the resulting item in the Income Statement. Different concepts of profit (Earnings Before Taxes, Earnings After Taxes, Earnings Before Interest and Taxes value before tax, after tax, value before interest, etc.) is the base for calculating the company's profitability. However, how companies subsequently treat net profit already depends on the owners' decision. The payment of dividends is legally limited only by the Act on Business Corporations No. 90/2012 Coll., where $\S 40$ states that a corporation may not pay a profit if it would lead to bankruptcy (i.e. it has more creditors and is unable to pay liabilities for more than 30 days after the due date). The owners of the company 
(partners, shareholders) decide at the annual general meeting how to deal with profit from the previous accounting period: if they do not have to cover the loss incurred in the past, they can invest it in various funds from profit, increase their share capital, transfer retained earnings to the account or, for example, to pay it out in the form of a profit share dividends to its shareholders. Deciding how to manage profits should be an important part of a company's long-term strategy.

Dividends reduce stockholders' equity and cash flow, which has an immediate impact on the company's liquidity.

The Czech Republic has consistently the third highest deficit in the income balance in relation to GDP in the entire EU for a long time (after Luxembourg and Ireland, specific economies that we can boldly call European tax havens). According to the government's analysis, which was based on data from the AMECO (annual macro-economic database of the European Directorate General for Economic and Financial Affairs), the outflow of capital gains adjusted from reinvestment has been increasing systematically since about 2000 . This is also evidenced by gross national income, which has been on average $8 \%$ lower than gross domestic product in the last ten years. [1]

According to the Czech Statistical Office, for example, in 2019 the profits of foreign owners reached almost CZK 401 billion, which represents 7.1\% of GDP. Foreign owners distributed CZK 319 billion in dividends and CZK 82 billion was reinvested. This development also reflects the high profitability of foreign direct investment in the Czech Republic. [2] In Figure 1 we can see the long-term trend of the outflow of profits abroad.

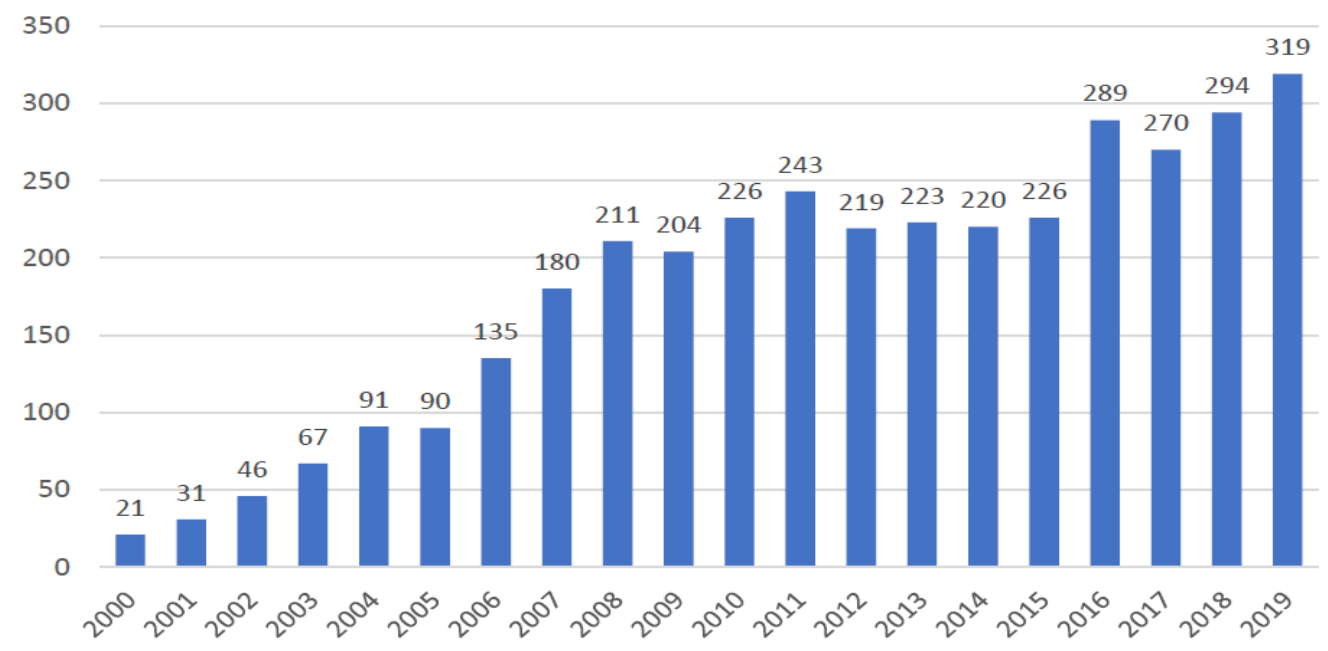

Figure 1: Outflow of profits from the Czech Republic abroad in billion CZK (source: The Czech Statistical Office, compilation of authors)

According to the Czech National Bank, the largest volumes of finance flowed into the Netherlands (CZK 58 billion, the Netherlands being the leader throughout the period analyzed), Luxembourg (CZK 57 billion) and Germany (CZK 44 billion) in 2019. The largest share by sector has Financial and insurance activities and Manufacturing. [3]

The trigger for this situation was the unprecedented opening of the Czech economy in the early 1990s as part of the Czech Republic's economic transformation from a centrally planned economy to a market economy. The Czechia wanted to attract foreign investors and opened its arms with generous investment incentives. These were provided by many countries, but the Czech Republic came up with an exceptional tax relief for investors for a period of ten years, direct subsidies for job creation, discounts on land purchases and the like. According to the European Statistical Office Eurostat, the Czech Republic has the lowest long-term unemployment rate in the entire EU. For example, in 2020, unemployment in the EU was above $7.5 \%$, in the Czech Republic it was below $3 \%$. 
The inflow of foreign investment from the 1990s is still reflected in the ownership structure of Czech companies: Registered capital (CZK billion) Czech owner 54.4\%, foreign owner 38.5\% (of which $13 \%$ are offshore companies), $7.1 \%$ untraceable owner. [4]

According to the employees of the companies in the hands of foreign capital, there is an opinion that foreign parent companies treat their Czech "daughters" too autocratically, do not give space to the initiative of Czech employees, even though they know the local conditions and working environment better, approval processes are lengthy. They underestimate Czech employees, which is subsequently reflected in lower wages, even for the same work.

The article focuses on the Czech construction industry and answers the question of how the largest Czech construction companies under the control of foreign parent contribute to the outflow of profits abroad, or whether they keep profits for the further development of their Czech companies. Analyzes are processed on a time series of 5 years (2014 - 2018). The authors relied on data from the financial statements and annual reports of these companies, which are mandatory publish on the website of the Czech Ministry of Justice https://or.justice.cz/ias/ui/rejstrik

\section{Results}

The four largest construction companies operating on the Czech market were selected. They are METROSTAV, SKANSKA, STRABAG and EUROVIA CS. They are the largest in terms of both turnover and number of employees. [5] Only METROSTAV is exclusively in the hands of Czech owners, the others are 100 percent owned by foreign capital. It will be interesting to compare the approach to the profit of Czech owners in comparison with foreign owners. For the sake of completeness, let us add that there are a huge number of small and medium-sized enterprises on the Czech construction market (in 2019: 180,479 entities, which employed 177,000 employees, which simply means that the vast majority of them are self-employed entities without employees). [6] To this end, we must mention that without foreign workers, the Czech construction industry would have big problems. The largest number of them come outside the EU, specifically from Ukraine. [7]

From the point of view of taxation, companies in the Czech Republic pay to the state budget an income tax $19 \%$ and subsequent profit shares, which they pay abroad, are no taxed. EU Member States are bound by Council Directive 2011/96 /EU on the common system of taxation applicable in the case of parent companies and subsidiaries, which requires not to tax the dividend of parent companies from subsidiaries. Unlike the situation where the owner of the company is a person, the share of the profit must be taxed by another so-called withholding tax (i.e. taxed a second time) at a rate of $15 \%$. This unfair double taxation of company owners who are persons compared to parent who are legal entities has been discussed in the Czech Republic for years, but so far there is no willingness of the government to change this situation.

But let's go back to the issue of the ownership structure of large construction companies and how these companies handle profits. 


\section{Analysis of METROSTAV}

The ownership structure consists only of Czech and some Slovak persons.

In the years 2014 - 2018, earnings before taxes ranged from CZK 450 to 550 million - see Figure 2.

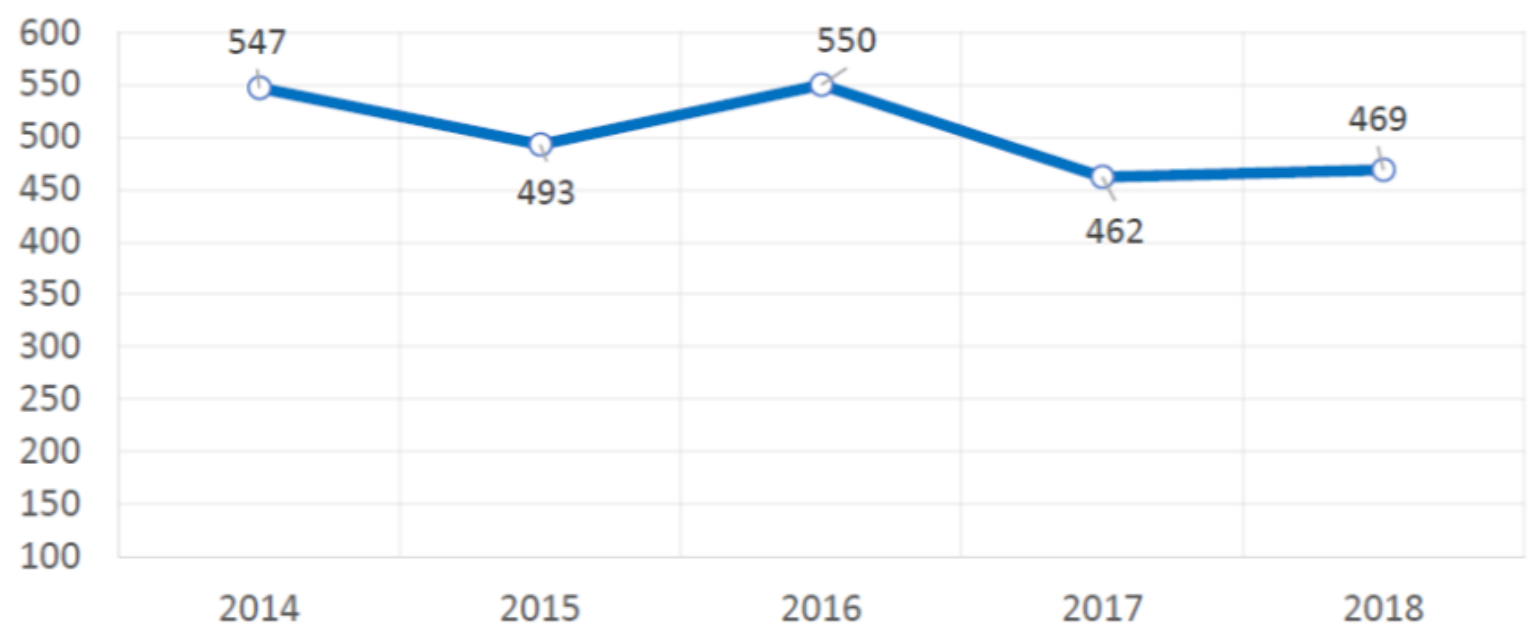

Figure 2: Earnings before taxes of METROSTAV (CZK million), (source: Annual report of METROSTAV 20142018, data processed by the authors)

METROSTAV's strategy in paying out profit shares in the years 2014 to 2018 was always the same. The management distributed approximately CZK 170 million annually. Since 2007, METROSTAV has been paying the same amount of profit share every year, namely CZK 21.50 per share. Figure 3 shows the volume of profit share outflow in CZK million (green) and the part of profit that was transferred to the retained earnings account (blue).

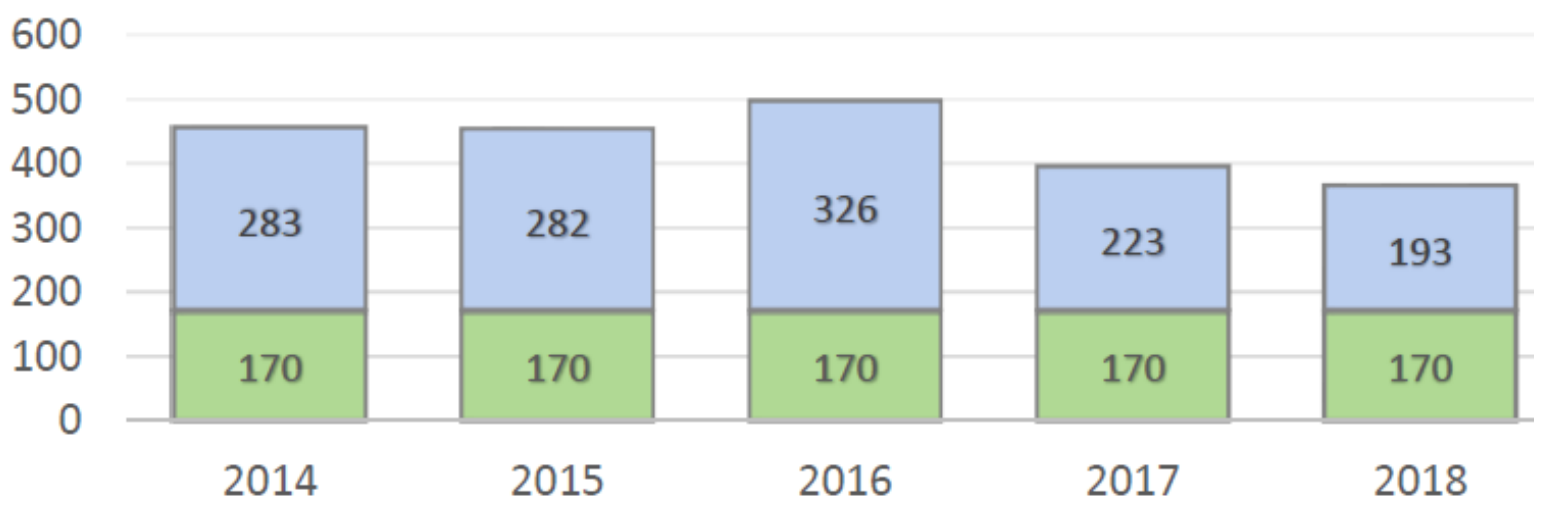

Figure 3: Payment of profit share and transfer to retained earnings account of METROSTAV (CZK million), (source: Annual report of METROSTAV 2014-2018, data processed by the authors)

In contrast to other large construction companies, which are controlled from abroad, METROSTAV approaches the payment of dividends with caution and keeps most of the profits in the company, which documents the growth of the retained earnings account - Figure 4. 


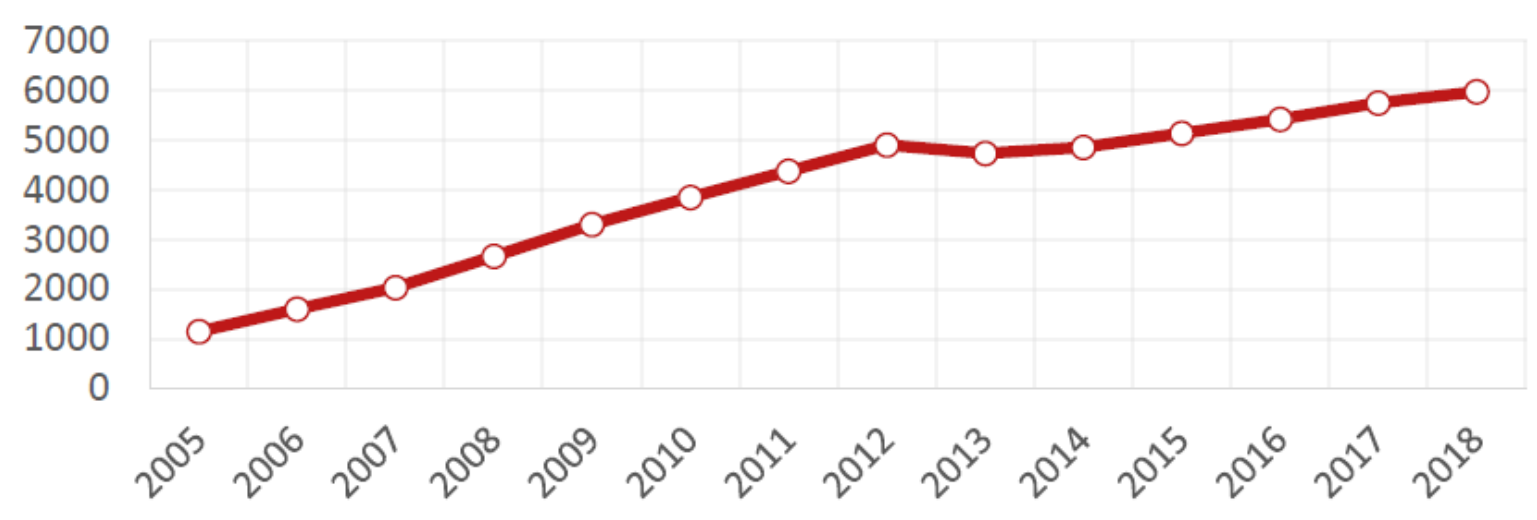

Figure 4: Growth in retained earnings account of METROSTAV (in millions of CZK), (source: Annual report of METROSTAV 2014-2018, data processed by the authors)

\section{Analysis of SKANSKA}

$67 \%$ of the company belongs to Swedish shareholders and the remaining $33 \%$ to foreign ones. At the same time, Swedish shareholders have $76.8 \%$ and foreign $23.2 \%$ of voting rights.

As we can see in Figure 5, SKANSKA suffered a loss of CZK 348 million in 2018.

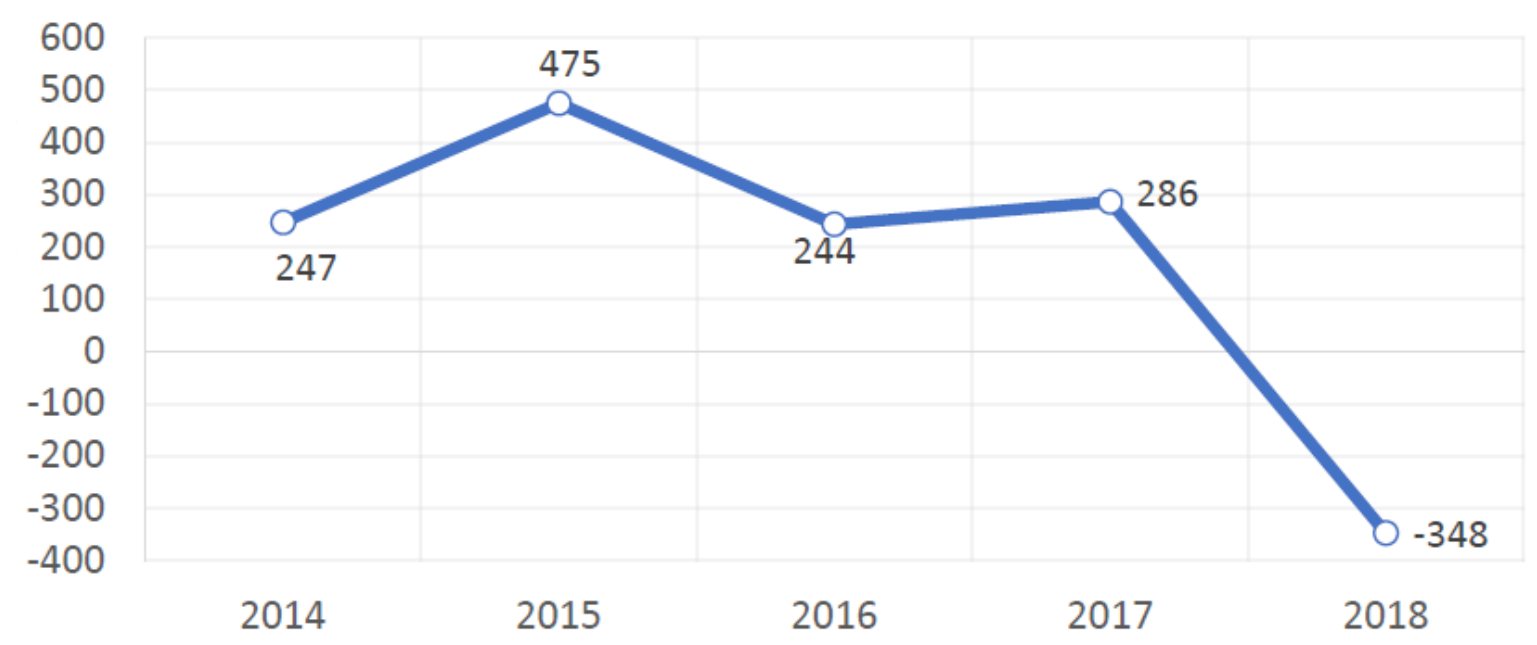

Figure 5: Earnings before taxes of SKANSKA (CZK million), (source: Annual report of SKANSKA 2014-2018, data processed by the authors)

In 2014, 2015 and 2016, SKANSKA transferred the profit to the retained earnings account of previous years. In 2015 and 2016, however, dividends totaling CZK 1.5 billion were paid from the same account. This resulted in a reduction of the amount in the retained earnings account by more than CZK 900 million. In 2017, SKANSKA paid out almost the entire profit (CZK 180 million). The loss (CZK -336.87 million) incurred in 2018 was transferred to the retained earnings account - see Figure 6 (in CZK million) - outflow of profit share (green) and part of the profit transferred to retained earnings account or from account drawn (blue). 


\section{0}

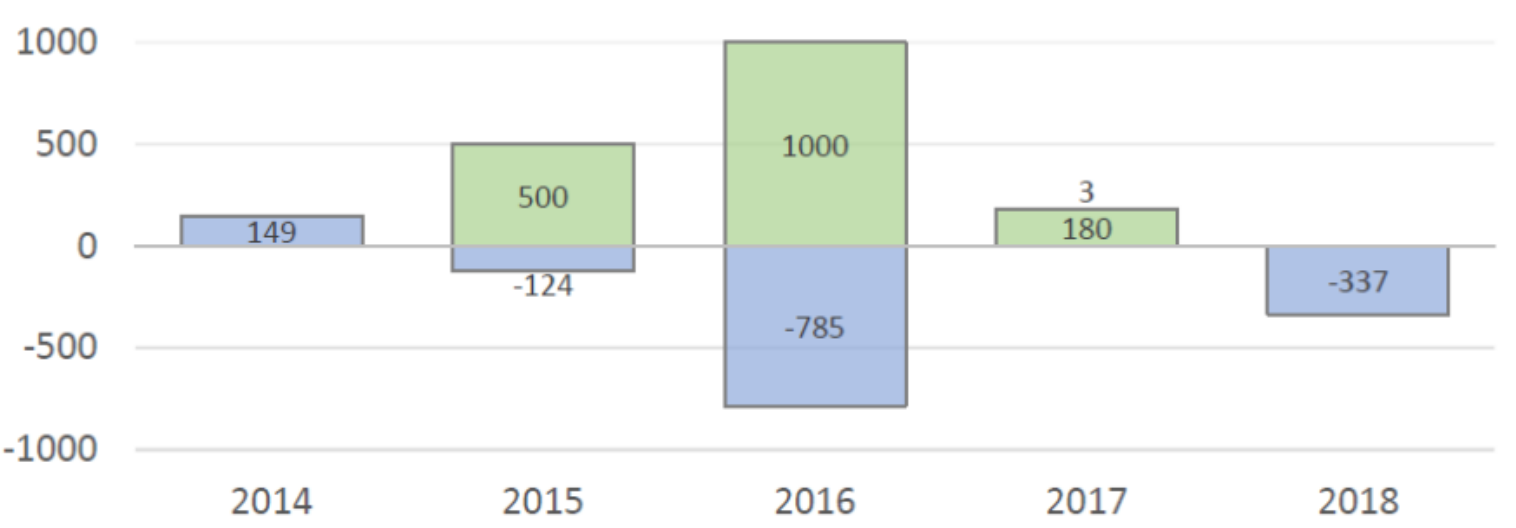

Figure 6: Outflow of profit share and movement on account SKANSKA's retained earnings (CZK million), (source: Annual report of SKANSKA 2014-2018, data processed by the authors)

The retained earnings account of SKANSKA decreased from 7 billion to 2.66 billion CZK over five years - see Figure 7. This is due to large dividend drawdowns in 2015 and 2016. In 2016, the company's dividends represent almost $39 \%$ of the total dividends in construction sector outflow abroad).

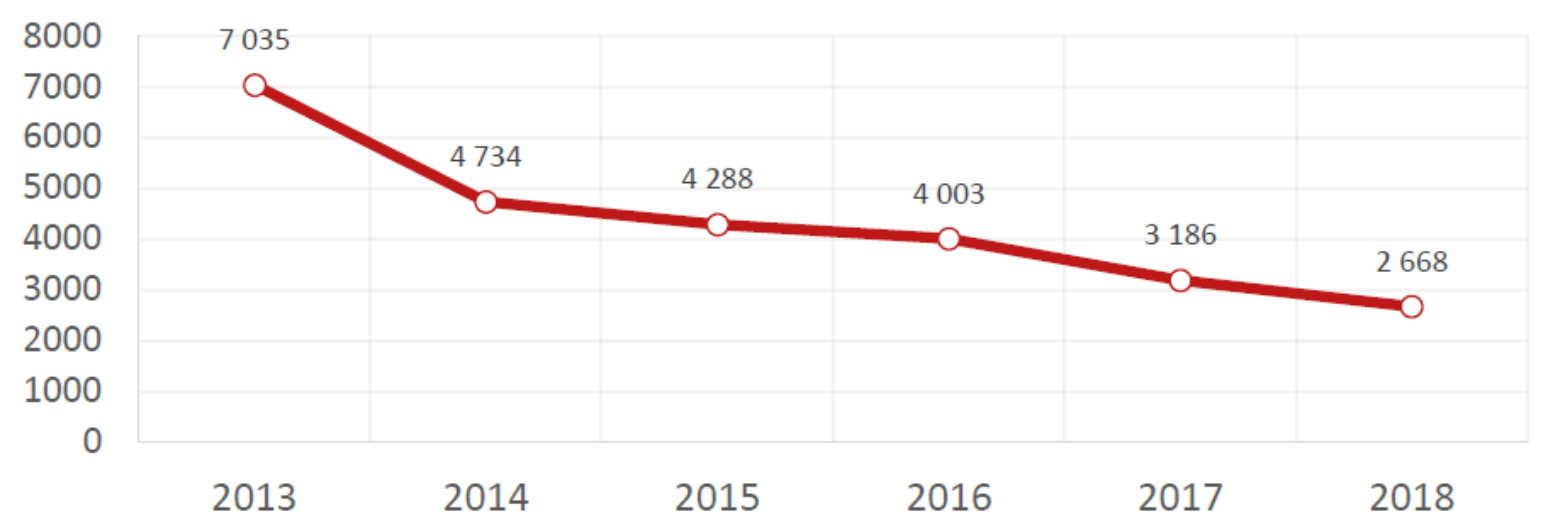

Figure 7: Decrease in the account of retained earnings SKANSKA (in CZK millions). (in millions of CZK), (source: Annual report of SKANSKA 2014-2018, data processed by the authors)

\section{Analysis of STRABAG}

The company is more than three quarters owned by Austrian entities, one quarter by Russian owners.

We can see how profit gained over time in the Figure 8 (in millions CZK). In 2015, the company recorded a loss of almost one hundred million CZK. 


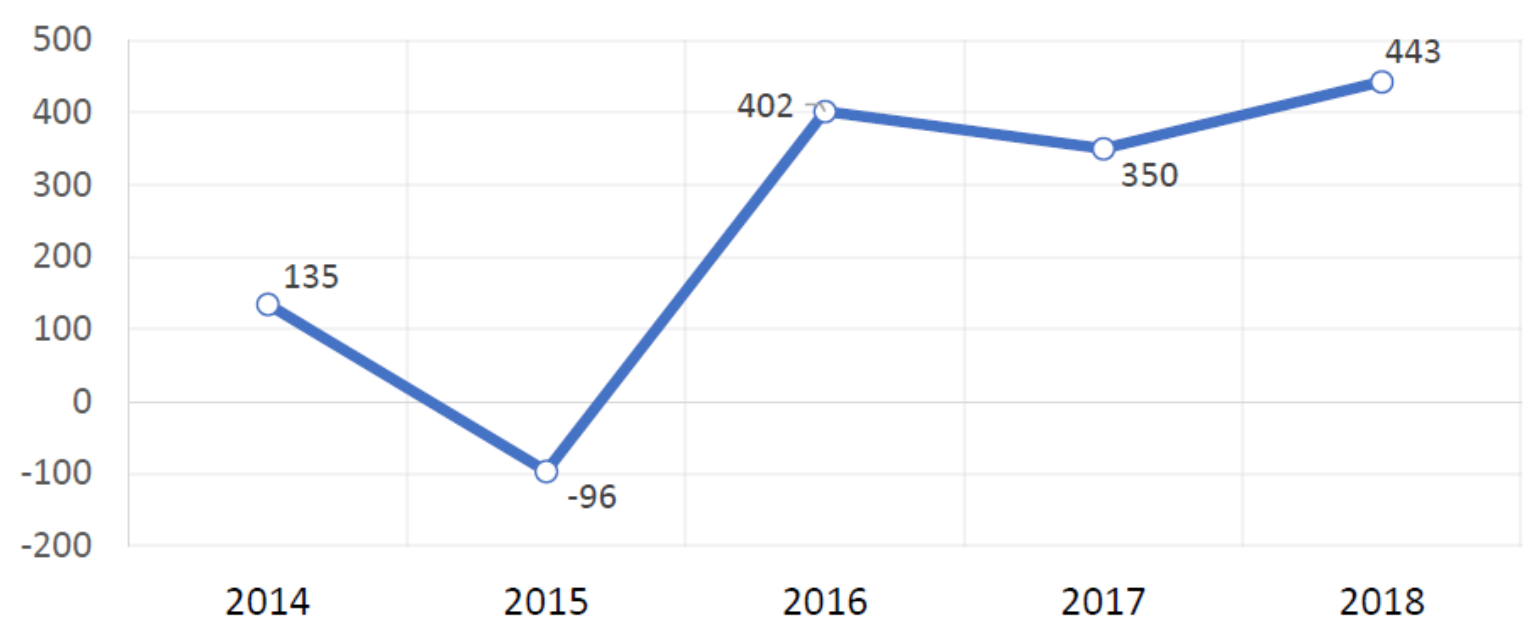

Figure 8: Earnings before taxes of STRABAG (CZK million), (source: Annual report of STRABAG 2014-2018, data processed by the authors)

Despite the reported loss in 2015, the management decided to pay out profit shares in the amount of CZK 300 million in 2016 (see Figure 9 - outflow profit share (green) and drawing from retained earnings account (blue). Likewise, in 2017, profit shares of CZK 500 million were outflow, of which CZK 200 million was paid out of the retained earnings account.

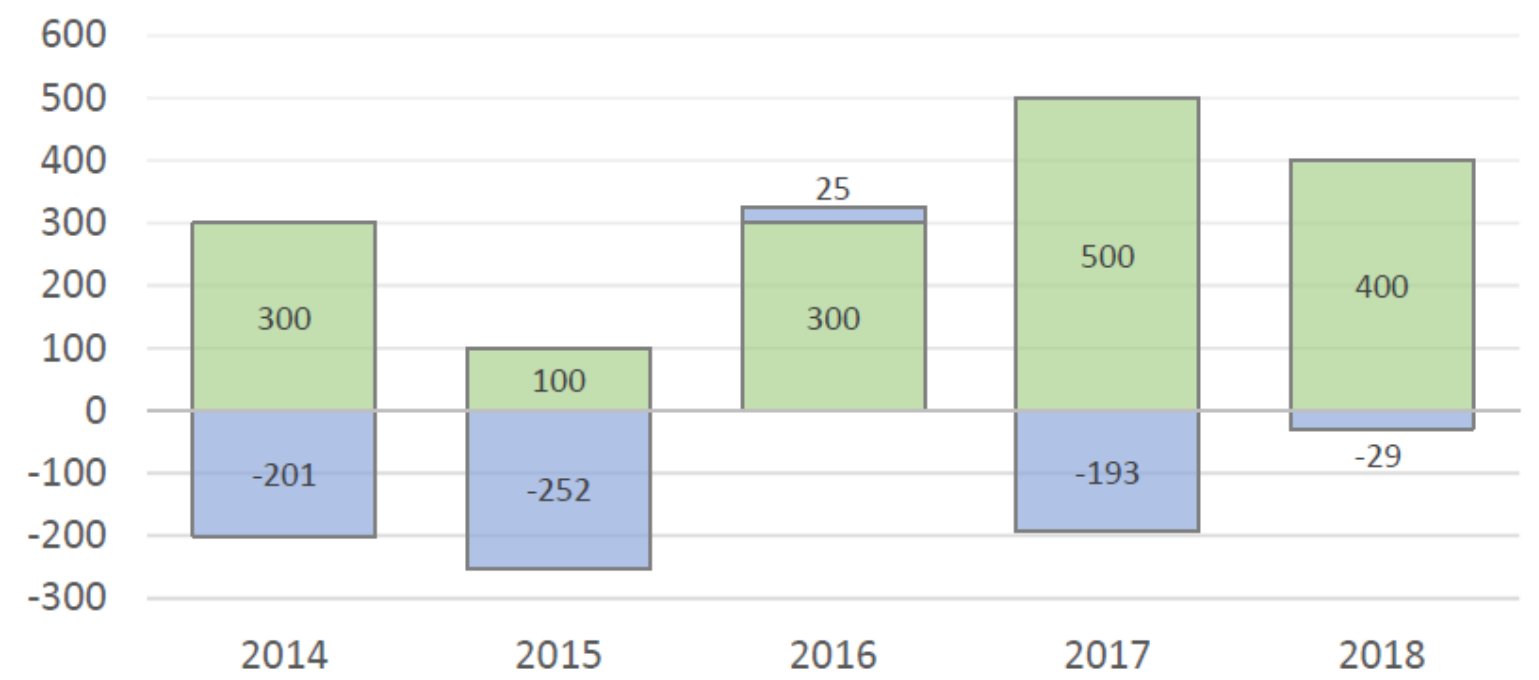

Figure 9: Outflow of profit share and withdrawal from retained earnings account STRABAG (CZK million), (source: Annual report of STRABAG 2014-2018, data processed by the authors)

The amount in the retained earnings account decreased until 2016. In 2017, the retained earnings account increased significantly, but the growth was not due to the transfer of profit, but the Austrian management decided to transfer a share premium of CZK 704 million to this account (see Figure 10, in CZK million). 


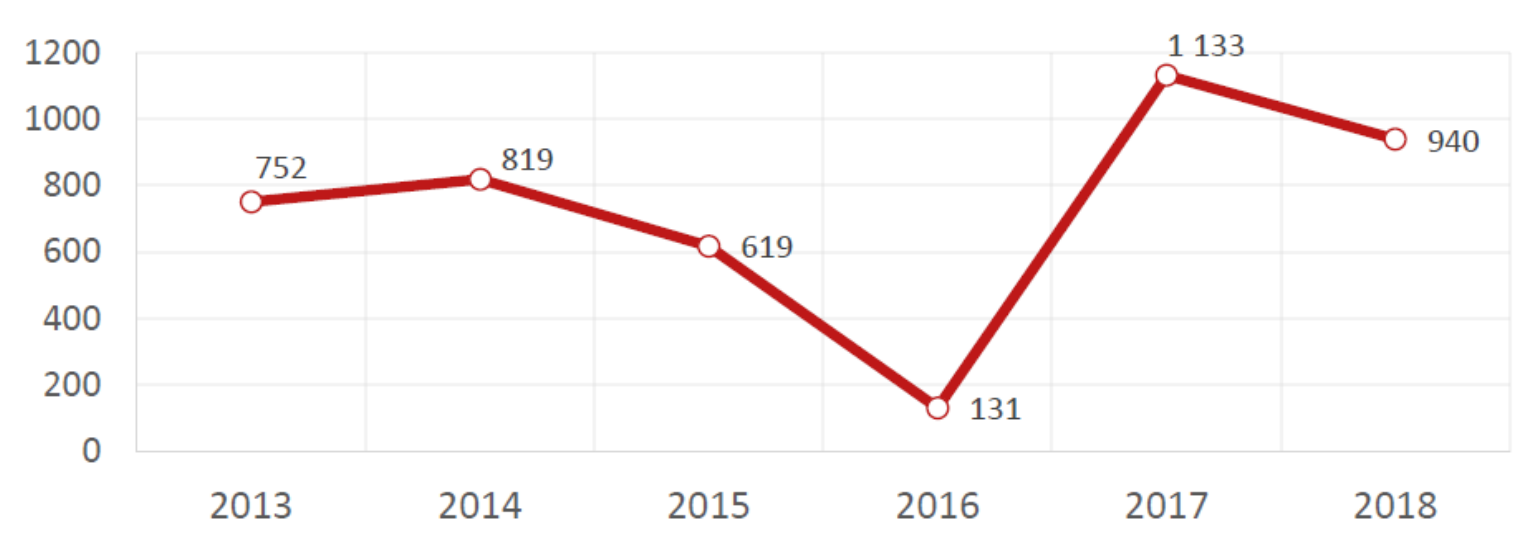

Figure 10: Movement on account retained earnings of STRABAG (in millions of CZK), (source: Annual report of STRABAG 2014-2018, data processed by the authors)

\section{Analysis of EUROVIA CS}

The company EUROVIA CS belongs to the French concern VINCl. The ownership structure of VINCI GROUP is quite diverse. North American companies have the largest share (22.9\%), French companies control $17.1 \%$, other European companies have $15.7 \%$ and companies from the United Kingdom also have a significant influence (11.7\%). The solid part of the shares belongs to the group's employees (8.8\%).

The earnings before taxes reached a significant increase in 2016, and the company was also very successful in the following years, see Figure 11 (millions of CZK).

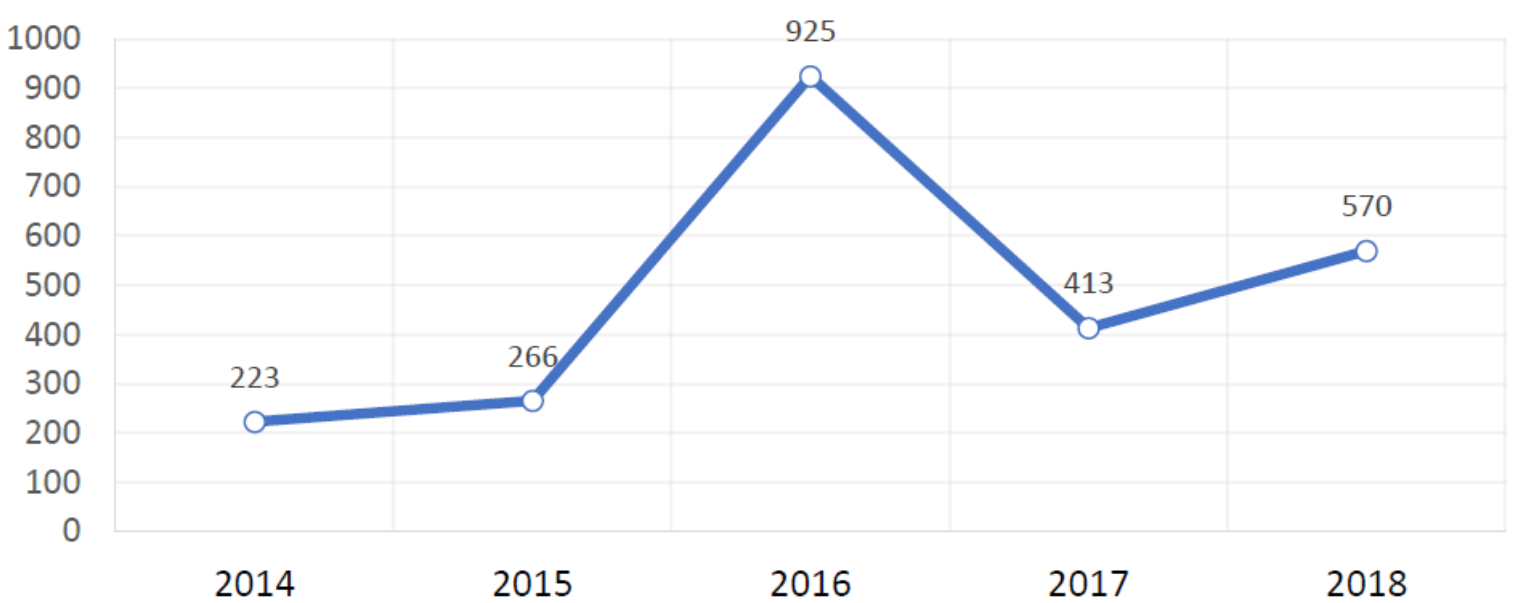

Figure 11: Earnings before taxes of EUROVIA CS (CZK million), (source: Annual report of EUROVIA CS 20142018, data processed by the authors)

In 2014, net income of CZK 216 million outflowed to France - see Figure 12, the profit share outflow (green) and part of the profit transferred to the retained earnings account (blue). The remaining 5.7 million crowns were transferred to the social fund account. In 2015, the company chose to deposit almost the net income to the retained earnings account and did not pay any dividends. As in the previous year, it deposited around 6 million crowns in the social fund. In the following years 2016 and 2017, the management decided in both cases to pay dividends 291.1 million crowns, while the remaining amount was deposited to the retained earnings account and to the account of the social fund. 


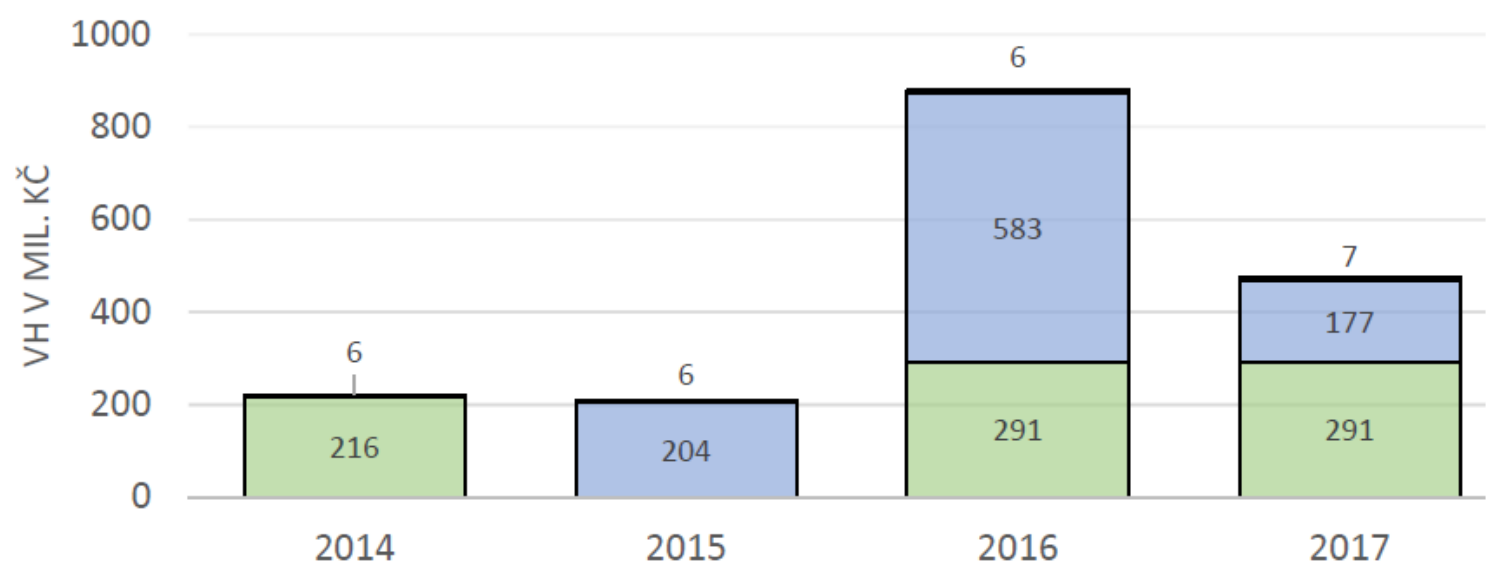

Figure 12: Outflow of profit share and increment retained earnings account of EUROVIA CS (CZK million), (source: Annual report of EUROVIA CS 2014-2018, data processed by the authors)

Careful drawing of dividends and the growth of the retained earnings account testify to the responsible behavior of EUROVIA CS (see Figure 13) and may also be related to the fact that the company has been operating on the Czech market for a relatively short time compared to its competitors.

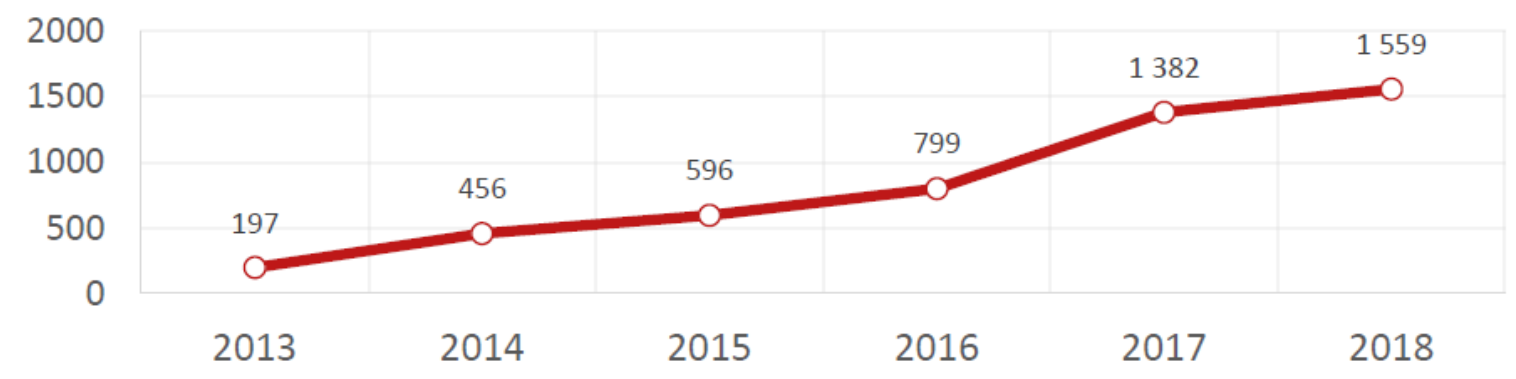

Figure 13: Gradual account growth of the retained earnings of EUROVIA CS (in millions of CZK), (source: Annual report of EUROVIA CS 2014-2018, data processed by the authors) 


\section{Conclusion and discussion details}

The caution in paying dividends was similar for the domestic company METROSTAV and the French company EUROVIA CS. Both companies preferred a more responsible strategy and preferred to keep most of the profits in their company. SKANSKA and STRABAG chose a less responsible strategy in the given period and, despite the declining volume of equity, continued to pay out high profit shares. Not only did they not reinvest their profits, but high dividends were largely paid out of retained earnings account. In this sense, SKANSKA is the leader, which paid dividends of CZK 1.5 billion in 2015 and 2016, while in previous years (2014 and 2015) reported a profit of approximately CZK 720 million (in 2016, the company's dividends paid amounted to almost $39 \%$ of the total outflow profit shares in the construction sector to abroad). STRABAG behaved similarly, profit shares were at the expense of retained earnings account and far exceeded reported profits. Finally, let us add that more important than the values themselves is the trend of the curve.

Every year, around 300 to 400 billion crowns outflow abroad from the Czech Republic through dividends. [8] The construction sector accounts for only about one percent of this total (Figure 14 - red line). Here we can confirm that the construction industry has a minimal share in making a profit abroad. The three largest construction companies in the hands of foreign owners (SKANSKA, STRABAG, EUROVIA CS) annually earn on average between 13\% and 60\% (in 2016 it was $60 \%$ mainly thanks to SKANSKA - CZK 1 billion) the amount of dividends outflow from the Czech Republic in the construction sector (see Figure 14 - blue line).

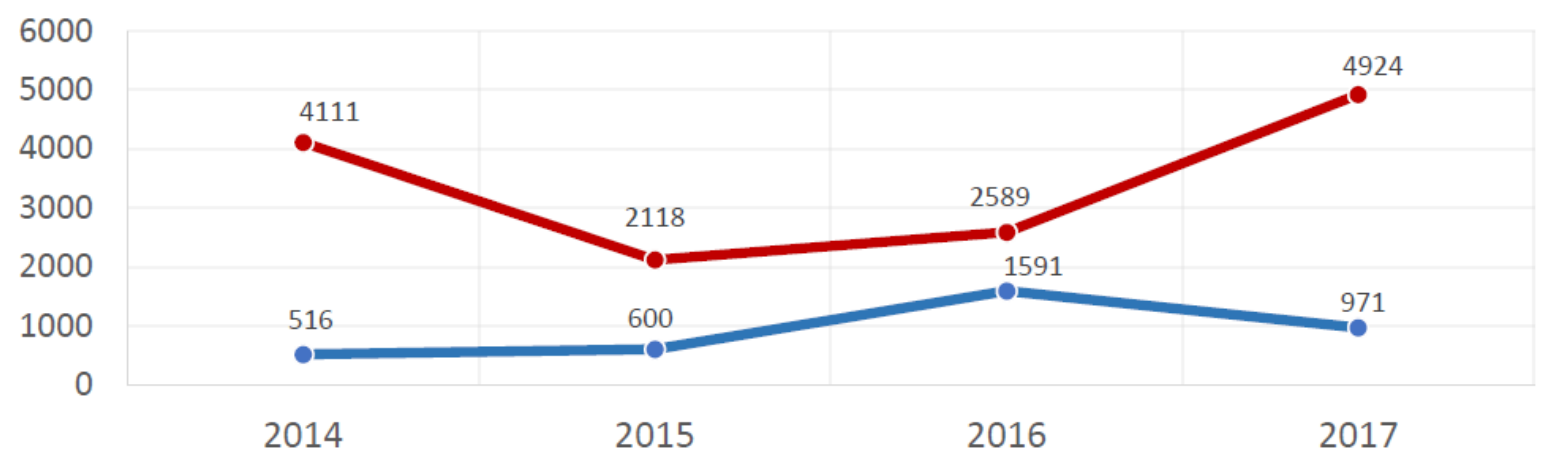

Figure 14: Outflow shares of profit from the Czech Republic in the construction sector (in millions of CZK), (source: Annual report of EUROVIA CS, SKANSKA, STRABAG 2014-2018, data processed by the authors, [8]

The steady outflow of revenues is the result of the opening of the Czech market and predatory entry of foreign capital in the late 1990s, which intensified later in 2004, when the Czech Republic joined the European Union (see Figure 1). There is no doubt that the inflow of foreign companies in the Czech Republic brought new investments, know-how and technology in its time. On the other hand, today, after about 25 years, foreign parent companies receive profit from their Czech daughters in the third largest volume of EU countries (in relation to GDP), which the Czech economy lacks for further development. Profits that are not reinvested but transferred from companies to foreign owners cause the companies to lose weight (reduce equity), with an immediate impact on its cash flow. [9] [10] However, as the results confirmed, the construction industry is negligible due to the outflow of total finances from the Czech Republic. 


\section{References}

[1] ÚŘAD VLÁDY ČESKÉ REPUBLIKY. Analýza odlivu zisků: Důsledky pro českou ekonomiku a návrhy opatření. Available online at: https://www.vlada.cz/assets/evropske-zalezitosti/analyzy-EU/Analyza-odlivuzisku.pdf (accessed 24 Jun 2021)

[2] CZECH STATISTICAL OfFiCE. Quarterly Sector Accounts - 4th quarter of 2019. Available online at: https://www.czso.cz/csu/czso/cri/ctvrtletni-sektorove-ucty-4-ctvrtleti-2019 (accessed 20 Jun 2021)

[3] CZECh NATIONAL BANK. Důchody z přímých investic. WEB PZI. Available online at: https://www.cnb.cz/analytics/saw.dll?PortalGo\&PortalPath=\%2Fshared\%2FPZI_WEB\%2FWEB_PZI\&Path =\%2Fshared\%2FPZI WEB\%2FPZI BPM6 5.1.\%20D\%C5\%AFchody Zem\%C4\%9B\&Style=CNB\&Done=Dash board\%26PortalPath\%3D\%252Fshared\%252FPZI WEB\%252FWEB PZI\%26Page\%3DPZI \%25C4\%258CR\% 26ViewState\%3Df55ks4rdu5djn2a6ccp7vtepsq\&Action=Prompt\&ViewState=f55ks4rdu5djn2a6ccp7vteps q\&P16=NavRuleDefault\&NavFromViewID=d\%3Adashboard p\%3Agmdgrelm1ou5sg4f (accessed 24 Jun 2021)

[4] BISNODE. Objem zahraničního kapitálu v tuzemských firmách atakuje historická maxima. Available online at: https://www.bisnode.cz/o-bisnode/o-nas/novinky/objem-zahranicniho-kapitalu-v-tuzemskychfirmach-atakuje-historicka-maxima/ (accessed 24 Jun 2021)

[5] CREDITREFORM. Firmy podnikající ve stavebnictví loni rostly, vlastníci jsou spokojeni. Available online at: https://www.imaterialy.cz/rubriky/aktuality/prumysl-a-obchod/firmy-podnikajici-ve-stavebnictvi-Ionirostly-vlastnici-jsou-spokojeni 47627.html (accessed 23 Jun 2021)

[6] MINISTERSTVO PRŮMYSLU AOBCHODU ČR. Zpráva ovývoji podnikatelského prostředí vČeské republice v roce 2019. Available online at: https://www.mpo.cz/assets/cz/podnikani/regulace-podnikani-a-snizovaniadministrativni-zateze/snizovani-administrativni-zateze-podnikatelu/2021/1/Zprava-2019.pdf (accessed 23 Jun 2021)

[7] CZeCh STATISTICAl OfFICE. Zaměstnaní cizinci. Available online at: https://vdb.czso.cz/vdbvo2/faces/index.jsf?page=vystupobjekt\&pvo=CIZ09\&z=T\&f=TABULKA\&katalog=31032\&str=v57614 (accessed 24 Jun 2021)

[8] CZECH NATIONAL BANK. Srovnání odlivu dividend v zemích Evropské unie. Available online at: https://www.cnb.cz/cs/menova-politika/zpravy-o-inflaci/tematicke-prilohy-a-boxy/Srovnani-odlivudividend-v-zemich-Evropske-unie (accessed 19 Jun 2021)

[9] Dariusz Siudak. The Influence of Interlocking Directorates on the Propensity of Dividend Payout to the Parent Company. Complexity, vol. 2020, Article ID 6262519, 16 pages, 2020. https://doi.org/10.1155/2020/6262519

[10] Lopes, Al, Lourenco, IC, Soliman, MT, Branco, MC. Is the relation between non-controlling interests and parent companies misleading? Australian journal of management. Vol. 46, issue 1, pages 24-50, February 2021, DOI: $10.1177 / 0312896219896388$ 